\title{
Weaning of Senegalese sole (Solea senegalensis) postlarvae to an inert diet with a co-feeding regime
}

\author{
Destete de postlarvas del lenguado senegalés (Solea senegalensis) a una dieta inerte \\ utilizando un régimen de coalimentación
}

\author{
Laura Ribeiro* \\ Sofia Engrola \\ Maria Teresa Dinis \\ Centro de Ciências do Mar \\ Universidade do Algarve \\ Campus de Gambelas \\ 8000-117 Faro, Portugal \\ *E-mail: mribeiro@ualg.pt
}

Recibido en octubre de 2003; aceptado en octubre de 2004

\begin{abstract}
The objective of this study was to evaluate the weaning success of Senegalese sole, Solea senegalensis, postlarvae when cofed a compound diet, by means of the analysis of growth parameters (relative growth rate $[R G R]$ and condition factor $[K]$ ), survival, protein and lipid content. Total ammonia in the rearing water was also measured. The experiment lasted for 46 days (36 to 82 days posthatching). One group was fed only with enriched Artemia sp. metanauplii (Artemia treatment), whereas in another group, the Artemia sp. metanauplii were gradually replaced by the International Council for the Exploration of the Sea (ICES) diet over a period of 39 days (ICES treatment). Postlarvae were sampled on rearing days 0, 9, 23, 30, 39 and 46 for growth and biochemical analysis. Water was sampled on rearing day 30 during a 24-h cycle in both treatments. Postlarvae from the ICES treatment were weaned, though by the end of the experiment the Artemia treatment exhibited significantly higher values for growth, $R G R, K$ and survival rates $(P<0.05)$. No significant differences were observed concerning total lipid content. Protein content was significantly higher for the Artemia treatment after 46 days of rearing $(P<0.05)$. The total ammonia nitrogen concentration in the water increased after each meal and remained below a harmless level for postlarvae.
\end{abstract}

Key words: flatfish, growth, inert diet, lipid, protein, weaning.

\section{Resumen}

El objetivo de este estudio consistió en evaluar el éxito del destete de postlarvas del lenguado senegalés, Solea senegalensis, utilizando un régimen de coalimentación. El estudio se realizó mediante el análisis de parámetros de crecimiento (tasa de crecimiento relativa $[R G R]$ y factor de condición $[K]$ ), supervivencia y contenido de proteínas y lípidos. La concentración del amonio total en el agua de cultivo también fue analizada. El experimento se realizó durante 46 días (de 36 a 82 días posteclosión). Un grupo de postlarvas se alimentó únicamente con metanauplios de Artemia sp. enriquecidos (tratamiento con Artemia), mientras que en otro grupo los metanauplius de Artemia sp. fueron gradualmente substituidos por la dieta del International Council for the Exploration of the Sea (tratamiento ICES) durante un periodo de 39 días. Las postlarvas se muestrearon durante los días $0,9,23,30$, 39 y 46 de cultivo para el estudio de crecimiento y el análisis bioquímico Las muestras de agua se tomaron el día 30 de cultivo durante un ciclo de $24 \mathrm{~h}$ en ambos tratamientos. Las postlarvas del tratamiento ICES fueron destetadas, aunque al final del experimento se registraron valores significativamente mayores en relación al crecimiento, $R G R, K$ y tasas de supervivencia $(P<0.05)$ en el tratamiento con Artemia. No se observaron diferencias significativas en el contenido total de lípidos. El contenido de proteínas fue significativamente mayor en el tratamiento con Artemia a los 46 días de cultivo $(P<0.05)$. La concentracion de amonio total en el agua se incrementó después de cada toma de alimento pero se mantuvo por debajo del nivel tóxico para las postlarvas de peces marinos.

Palabras clave: alimento inerte, crecimiento, destete, lípido, peces planos, proteína.

\section{Introduction}

The need for diversification of cultured species increased the interest of fish farmers for Senegalese sole, Solea senegalensis, a highly economical species commonly exploited in southern Europe (Dinis et al., 1999). The high growth and

\section{Introducción}

La necesidad de diversificar las especies cultivadas ha propiciado un creciente interés por parte de criadores de peces en el lenguado senegalés, Solea senegalensis, una especie de importancia comercial explotada en el sur de Europa (Dinis et 
survival rates observed during larval stages (Dinis et al., 1999) and the recent advances in weaning (Day et al., 1997; Cañavate and Fernández-Díaz, 1999; Engrola et al., 2001) provided encouraging perspectives for sole aquaculture.

Live food provides higher growth and survival rates in the early life stages when compared with compound diets (PersonLe-Ruyet et al., 1993; Blair et al., 2003). Nevertheless, some disadvantages have been pointed out concerning the use of live feeds, since they may act as vectors of diseases, their nutritional value can be variable, their nutritional quality is difficult to manipulate and they are time-consuming to produce and, consequently, expensive (Hart and Purser, 1996). These reasons led to the research of suitable diets in order to replace live food in the early stages of marine fish larvae. Until now only sea bass larvae have been reared successfully on an artificial diet from the time of mouth opening (Cahu and ZamboninoInfante, 2001).

Co-feeding of fish has been shown to enhance larval performance (Kanazawa et al., 1989; Cañavate and FernándezDíaz, 1999; Baskerville-Bridges and Kling, 2000), and to allow weaning in a shorter time (Person-Le-Ruyet et al., 1993).

The aim of this study was to evaluate the weaning success of $S$. senegalensis postlarvae when co-fed with a compound diet, through the analysis of growth, survival, and protein and total lipid contents. To assess the effect of the diet on water quality, total ammonia nitrogen (TAN; sum of ionized, $\mathrm{NH}_{4}{ }^{+}$, and unionized, $\mathrm{NH}_{3}$, form of ammonia) was also determined.

\section{Materials and methods}

\section{Postlarval rearing}

Eggs were obtained by natural spawning, from a broodstock adapted to captivity at the University of Algarve (Portugal). Senegalese sole larvae were reared using the same conditions described by Ribeiro et al. (1999b). At 25 days posthatching (dph), postlarvae were transferred from the larval rearing tanks to six square, flat-bottom tanks $(50 \mathrm{~cm}$ side, $40 \mathrm{~cm}$ deep) at a density of 2000 larvae $\mathrm{m}^{-2}$. Postlarvae were reared in $8 \mathrm{~cm}$ water column $(20 \mathrm{~L})$ under natural photoperiod (spring season). Seawater was supplied to each tank at an average rate $100 \pm 20 \mathrm{~mL} \mathrm{~min}^{-1}$. During the acclimation period (25-35 dph), fish were fed enriched Artemia sp. metanauplii. Live food was enriched with microalgae (Tetraselmis chui and Isochrysis galbana, 1:1). During the experimental period, temperature was maintained at $20 \pm 3^{\circ} \mathrm{C}$, salinity at $36.5 \pm 3.5 \mathrm{~g} \mathrm{~L}^{-1}$ and oxygen at $90 \pm 5 \%$ of saturation.

The standard International Council for the Exploration of the Sea diet (ICES Laboratory of Aquaculture and Artemia Reference Center, Belgium) was specially formulated for marine fish larvae in order to allow comparisons of data on fish nutrition from different laboratories (Coutteau et al., 1995). Diet formulation is reported in Coutteau et al. (1995) and the batch used was ICES895. From preliminary experiments with al., 1999). Las altas tasas de crecimiento y supervivencia registradas para los estadios larvales (Dinis et al., 1999) y los avances recientes obtenidos en el destete (Day et al., 1997; Cañavate y Fernández-Díaz, 1999; Engrola et al., 2001) han proporcionado buenas perspectivas para la acuicultura del lenguado.

El uso de alimento vivo proporciona mayores tasas de supervivencia y crecimiento en los estadios tempranos en comparación con dietas compuestas (Person-Le-Ruyet et al., 1993; Blair et al., 2003). No obstante, se han mencionado algunas desventajas con respecto al uso de alimentos vivos, ya que pueden actuar como vectores de enfermedades, su valor nutricional puede ser variable, su calidad nutricional es difícil de manipular y su producción es tardada y, por lo tanto, costosa (Hart y Purser, 1996). Por estas causas, se han realizado investigaciones para determinar dietas adecuadas para substituir el alimento vivo en los primeros estadios larvarios de peces marinos. A la fecha, sólo se han podido cultivar con éxito las larvas de lubina con una dieta artificial a partir de que éstas pueden abrir la boca (Cahu y Zambonino-Infante, 2001).

Se ha encontrado que la coalimentación de peces mejora el desempeño larval (Kanazawa et al., 1989; Cañavate y Fernández-Díaz, 1999; Baskerville-Bridges y Kling, 2000) y permite el destete en menos tiempo (Person-Le-Ruyet et al., 1993).

El objetivo del presente estudio fue evaluar el éxito en el destete de postlarvas de $S$. senegalensis al ser coalimentadas con una dieta compuesta, mediante el análisis del crecimiento, la supervivencia y los contenidos de proteína y lípidos totales. Para evaluar el efecto de la dieta en la calidad del agua, también se determinó la concentración de amonio total (suma de las formas ionizada, $\mathrm{NH}_{4}^{+}$, y no ionizada, $\mathrm{NH}_{3}$, del amonio; TAN por sus siglas en inglés).

\section{Materiales y métodos}

\section{Cultivo de postlarvas}

Los huevos fueron obtenidos mediante desove natural, de reproductores en cautiverio en la Universidad de Algarve (Portugal). Se cultivaron larvas de S. senegalensis bajo las condiciones descritas por Ribeiro et al. (1999b). A los 25 días después de la eclosión (dde), las postlarvas fueron transferidas del tanque de cultivo larvario a seis tanques cuadrados de fondo plano (50 cm de lado, $40 \mathrm{~cm}$ de profundidad), a una densidad de 2000 larvas $\mathrm{m}^{-2}$. Las postlarvas se cultivaron en una columna de agua de $8 \mathrm{~cm}(20 \mathrm{~L})$ bajo fotoperiodo natural (primavera). Se suministró agua de mar a cada tanque a una tasa media de $100 \pm 20 \mathrm{~mL} \mathrm{~min}^{-1}$. Durante el periodo de aclimatación (25 a 35 dde), los peces fueron alimentados con metanauplios de Artemia sp. enriquecidos. El alimento vivo fue enriquecido con microalgas (Tetraselmis chui e Isochrysis galbana, 1:1). Durante el periodo experimental, se mantuvo la temperatura a $20 \pm 3^{\circ} \mathrm{C}$, la salinidad a $36.5 \pm 3.5 \mathrm{~g} \mathrm{~L}^{-1}$ y el oxígeno a $90 \pm 5 \%$ de saturación. 
Senegalese sole (Ribeiro et al., 1999a), higher survival and growth rates were obtained when feeding postlarvae the ICES diet with 3\% less lipids on the coating than the standard diet.

The moment to start the weaning was based on the fact that Senegalese sole exhibits a histologically differentiated stomach around $30 \mathrm{dph}$ (Ribeiro et al., 1999b).

The experiment lasted 46 rearing (R) days: R0 (36 dph) to R46 (82 dph). In three randomly selected tanks, fish received the ICES diet with 3\% less lipids on the coating (ICES treatment), while in the remaining three tanks, fish were fed with enriched Artemia sp. metanauplii (Artemia treatment). Postlarvae were fed twice a day (11:00 and 17:00 h) and the quantity of food was determined based on the predicted maximum growth attainable, which takes into consideration the postlarval growth rate and the feeding conversion efficiency. The weekly wet weight determinations of postlarvae allowed adjustments to the amount of food offered the postlarvae. During the co-feeding period, the ICES diet was gradually introduced, resulting in the total substitution of Artemia metanauplii at day R39 (percentage of ICES diet: 10\% at day R0, 50\% at day R19 and 100\% at day R39).

Tanks were cleaned every day and dead postlarvae were removed and counted for survival rate determination.

Postlarvae were sampled before feeding at days R0, R9, R30, R39 and R46 for length and weight measurements (15 individuals per tank) and for biochemical analysis (a pool of 30 postlarvae per tank).

Total length was determined by measuring 15 postlarvae. After careful rinsing with distilled water and dry blotting with a paper towel, these postlarvae were weighed. Postlarvae were then individually frozen in liquid nitrogen and subsequently freeze-dried; dry weight was determined in a microbalance at the laboratory.

The condition factor $(K)$ was calculated according to Jobling (1994):

$$
K \% \text { = wet weight } / \text { length }^{3} \times 100
$$

The relative growth rate $(R G R)$ was calculated according to Ricker (1958):

$$
\begin{gathered}
R G R\left[\% \mathrm{~d}^{-1}\right]=\left(\mathrm{e}^{\mathrm{g}}-1\right) \times 100, \mathrm{~g}=\left(\ln \mathrm{ps}_{\mathrm{f}}-\ln \mathrm{ps}_{\mathrm{i}}\right) /\left(\mathrm{t}_{\mathrm{f}}-\mathrm{t}_{\mathrm{i}}\right) \\
\text { ps }=\text { dry weight and } \mathrm{t}=\text { days }
\end{gathered}
$$

For the biochemical analysis (protein and lipid content), samples were carefully rinsed with distilled water and immediately frozen in liquid nitrogen. Protein content was determined according to the method of Lowry et al. (1951), with an adaptation of Rutter (1967). Total lipids were determined gravimetrically after extraction with chloroform/ methanol based on the method of Bligh and Dyer (1959). A micro- balance was used to gravimetrically determine total lipids.
La dieta estándar de ICES (Laboratorio de Acuicultura y Centro de Referencia de Artemia, Bélgica) fue formulada especialmente para larvas de peces marinos para permitir comparar los datos sobre la alimentación de peces de diferentes laboratorios (Coutteau et al., 1995). La formulación de la dieta se encuentra en Coutteau et al. (1995) y se utilizó el lote ICES895. Experimentos previos con S. senegalensis (Ribeiro et al., 1999a) mostraron que se obtienen mayores tasas de crecimiento y supervivencia cuando las postlarvas se alimentan con la dieta de ICES con 3\% menos de lípidos en la cubierta que con la dieta estándar.

El momento de empezar el destete se determinó tomando en cuenta que $S$. senegalensis presenta un estómago histológicamente diferenciado alrededor de 30 dde (Ribeiro et al., 1999b).

El experimento tuvo una duración de 46 días de cultivo: del día 0 (36 dde) al día 46 (82 dde). En tres tanques escogidos aleatoriamente, los peces fueron alimentados con la dieta ICES con 3\% menos de lípidos en la cubierta (tratamiento ICES), mientras que en los otros tres tanques los peces fueron alimentados con metanauplios de Artemia sp. enriquecidos (tratamiento con Artemia). Las postlarvas fueron alimentadas dos veces al día (11:00 y 17:00 h) y la cantidad de comida se determinó de acuerdo con el crecimiento máximo alcanzable pronosticado, el cual considera la tasa de crecimiento postlarval y la eficiencia de conversión alimenticia. Las determinaciones semanales de peso húmedo de las postlarvas permitió ajustar la cantidad de comida que se les suministraba. Durante el periodo de coalimentación, la dieta ICES fue introducida gradualmente, hasta alcanzar una substitución total de los metanauplios de Artemia sp. el día 39 de cultivo (porcentaje de la dieta ICES: $10 \%$ al día 0, 50\% al día 19 y 100\% al día 39 de cultivo).

Los tanques fueron lavados todos los días y las postlarvas muertas fueron retiradas y contadas para determinar la tasa de supervivencia.

Antes de suministrar el alimento los días 0, 9, 30, 39 y 46 de cultivo, se tomaron muestras de postlarvas para medir su longitud y peso (15 individuos por tanque) y para su análisis bioquímico (lote de 30 postlarvas por tanque).

Para determinar la longitud total se midieron 15 postlarvas, las cuales fueron lavadas cuidadosamente con agua destilada y secadas con papel secante antes de ser pesadas. Posteriormente se congelaron individualmente en nitrógeno líquido y se liofilizaron; el peso seco se determinó usando una microbalanza en el laboratorio.

El factor de condición $(K)$ se calculó de acuerdo con Jobling (1994):

$$
K \% \text { = peso húmedo } / \text { longitud }^{3} \times 100
$$

La tasa de crecimiento relativo (TCR) se calculó según Ricker (1958):

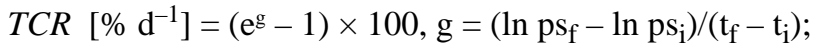

$$
\begin{aligned}
& \mathrm{ps}=\text { peso seco } \mathrm{y} \mathrm{t}=\text { días }
\end{aligned}
$$


The TAN concentration in the tank water was monitored over a period of $24 \mathrm{~h}$ on day R30, when the compound diet comprised $60 \%$ of the daily ration in the ICES treatment. Water was sampled the morning before and after the purge (point AP in figs. 1 and 2) in the tanks. Samples were also collected during the morning meal (point 0 in figs. 1 and 2) and one, two, two and a half, three, three and a half and four hours after this meal, and during the afternoon meal (point 0Af in figs. 1 and 2) and one hour after this meal. The next morning, water was again sampled before (BP24 in figs. 1 and 2) and after purging the tanks. Sampling was carried out in two tanks: one tank from the Artemia treatment and the other from the ICES treatment. At every sampling point, water was also sampled from the inlet to control the background ammonia levels in the water.

Samples were analyzed in triplicate for TAN concentrations in the water using the indophenol method (Koroleff, 1983).

The length and weight data were log-transformed, while the data expressed as a percentage (protein, lipid, $R G R, K$, survival) were arcsin-transformed (Sokal and Rohlf, 1995). Variance homogeneity was verified by Levene's test. The effect of the treatment was analyzed through the comparison of means by one-way ANOVA. Differences were considered significant for an $\alpha=0.05$ level. The statistical analysis was done using the SPSS software for Windows version 10.0 (SPSS Inc.).

\section{Results}

\section{Growth parameters}

Fish fed with the Artemia diet exhibited higher survival rates than the fish fed with the ICES diet $(P<0.05)$ (table 1$)$.

Fish growth adjusted to an exponential curve for both treatments, although the Artemia treatment exhibited a better fit to this curve ( $r=0.97)$ than the ICES treatment ( $r=0.81)$ (fig. 3). From day R23 onwards, postlarvae from the Artemia treatment exhibited a significantly higher dry weight value than those from the ICES treatment (table 1). This difference was concomitant with the increase in the quantity of ICES diet in the daily ration to more than $50 \%$, resulting in a $30 \%$ decrease in weight at day R39. From this moment onwards, the fish were able to recover their weight. Size dispersion was more evident in the Artemia treatment, and increased during the experimental period. A similar pattern was observed for the ICES treatment, although a decrease was observed on day R39.

The $R G R$ presented a strong variation during the experimental period, decreasing after day R23 and increasing again at the end of the experiment. The decrease was more evident in the ICES treatment, especially on days R30 and R39 when negative $R G R$ values were obtained (table 1). Nevertheless, ICES-fed postlarvae were able to recover, exhibiting a higher value for RGR on day R46 than the Artemia-fed postlarvae. The overall $R G R$ was significantly higher for the Artemia
Para el análisis bioquímico (contenido de proteína y lípidos), las muestras fueron lavadas cuidadosamente con agua destilada e inmediatamente congeladas en nitrógeno líquido. El contenido de proteína se determinó siguiendo el método de Lowry et al. (1951), con una adaptación de Rutter (1967). Los lípidos totales fueron determinados gravimétricamente después de la extracción con cloroformo/metanol de acuerdo con el método de Bligh y Dyer (1959), utilizando una microbalanza.

La concentración de TAN en el agua de los tanques fue observada durante 24 h el día 30 de cultivo, cuando la dieta compuesta comprendía $60 \%$ de la ración diaria en el tratamiento ICES. El agua se muestreó antes y después de la purga (punto AP en figs. 1 y 2) en los tanques. Se recolectaron muestras durante el proceso matutino de alimentación (punto 0 en figs. 1 y 2) y una, dos, dos y media, tres, tres y media, y cuatro horas después, así como durante la alimentación vespertina (punto 0Af en figs. 1 y 2) y una hora después de ésta. La mañana siguiente se volvió a muestrear el agua antes (punto BP24 en figs. 1 y 2) y después de la purga en los tanques. El muestreo se llevó a cabo en dos tanques, uno con el tratamiento con Artemia y otro con el tratamiento ICES. En todos los puntos del muestreo se analizó también el agua suministrada, a fin de controlar los niveles de amonio en el medio.

Las muestras se analizaron por triplicado para determinar las concentraciones de TAN en el agua mediante el método del indofenol (Koroleff, 1983).

Los datos de longitud y peso fueron transformados a logaritmos, mientras que los datos expresados como porcentaje (proteína, lípidos, TCR, $K$, supervivencia) fueron transformados a su arco seno (Sokal y Rohlf, 1995). La homogeneidad de varianza se verificó utilizando la prueba de Levene. El efecto del tratamiento se analizó mediante comparación de medias por análisis de varianza de una vía. Las diferencias se consideraron significativas a un nivel de $\alpha=0.05$. En el análisis estadístico se utilizó el programa SPSS para Windows versión 10.0 (SPSS Inc.).

\section{Resultados}

\section{Parámetros de crecimiento}

Los peces alimentados con la dieta de Artemia presentaron mayores tasas de supervivencia que los peces alimentados con la dieta ICES $(P<0.05)$ (tabla 1$)$.

En ambos tratamientos, el crecimiento de los peces se ajustó a una curva exponencial, aunque el tratamiento con Artemia mostró un mejor ajuste a esta curva $(r=0.97)$ que el tratamiento ICES ( $r=0.81$ ) (fig. 3). A partir del día 23 de cultivo, las postlarvas del tratamiento con Artemia presentaron un peso seco significativamente mayor que las del tratamiento ICES (tabla 1). Esta diferencia coincidió con el incremento en la cantidad de la dieta ICES en la ración diaria a más de 50\%, registrándose una disminución en peso de $30 \%$ el día 39 de cultivo. A partir de ese momento, los peces pudieron recuperar su peso. La dispersión de talla fue más evidente en el 


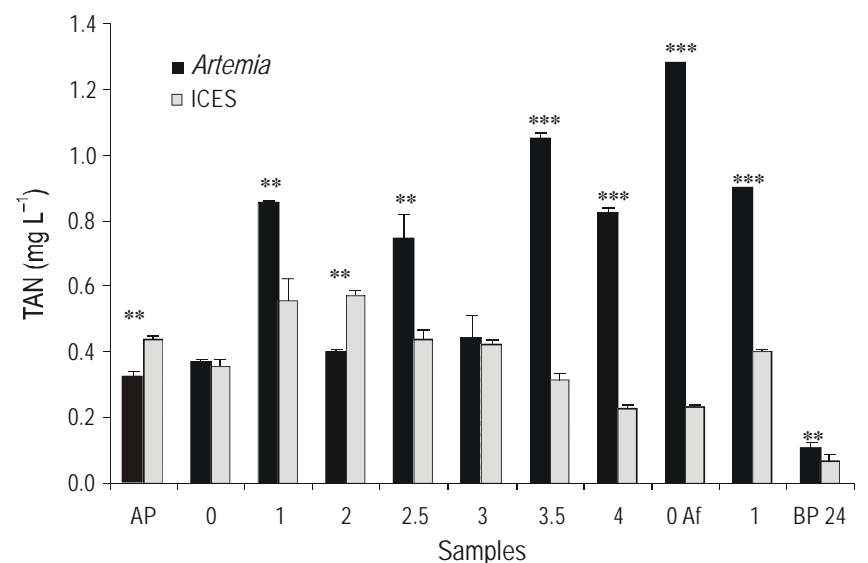

Figure 1. Total ammonia in the rearing water at rearing day 30 of Solea senegalensis postlarvae under the Artemia (Artemia sp. metanauplii) and ICES (co-feeding diet) treatments. Means $\pm S D, n=3$. AP $=$ after the purge, $0=$ first meal, $0 A f=$ afternoon meal, and BP24 = before the purge 24 hours after first purge.

Figura 1. Amonio total en el agua de cultivo al día 30 de cultivo de postlarvas de Solea senegalensis bajo los tratamientos con Artemia (metanauplios de Artemia sp.) e ICES (dieta de coalimentación). Medias \pm $\mathrm{DE}, n=3$. AP $=$ después de la depuración, $0=$ primer alimento, $0 \mathrm{Af}=$ alimento vespertino y BP24 = antes de la depuración 24 h después de la primera depuración.

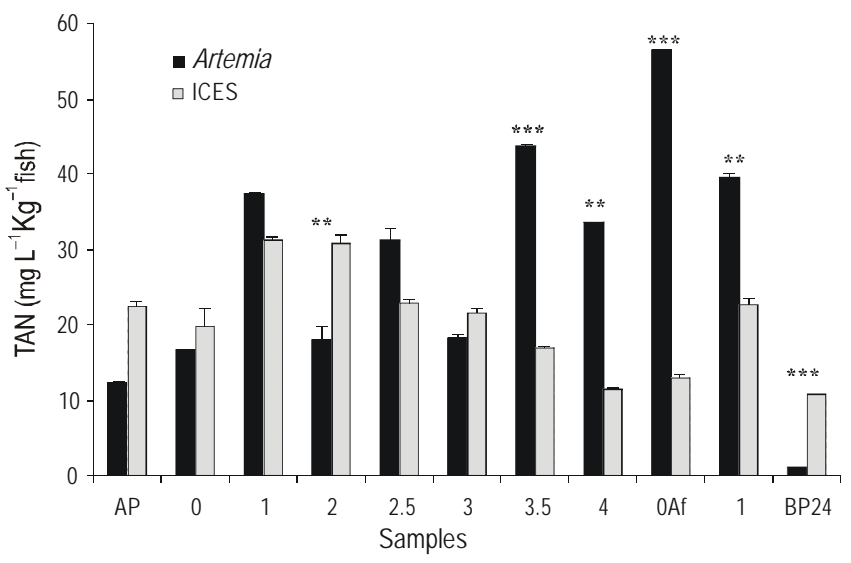

Figure 2. Total ammonia in the rearing water at rearing day 30 of Solea senegalensis postlarvae under Artemia (Artemia sp. metanauplii) and ICES (co-feeding diet) treatments expressed by fish biomass. Means $\pm \mathrm{SD}, n=$ 3. $A P=$ after the purge, $0=$ first meal, $0 A f=$ afternoon meal, and $B P 24=$ before the purge 24 hours after first purge.

Figura 2. Amonio total en el agua de cultivo al día 30 de cultivo de postlarvas de Solea senegalensis bajo los tratamientos con Artemia (metanauplios de Artemia sp.) e ICES (dieta de coalimentación) expresado según la biomasa de peces. Medias $\pm \mathrm{DE}, n=3$. AP $=$ después de la depuración, $0=$ primer alimento, 0 Af $=$ alimento vespertino y BP24 = antes de la depuración $24 \mathrm{~h}$ después de la primera depuración.

Table 1. Summary of dry weight, length, relative growth rate (RGR), condition factor (K) and survival of Solea senegalensis postlarvae under the Artemia (Artemia sp. metanauplii) and ICES (co-feeding diet) treatments. Means in a column bearing different letters are significantly different at $\alpha=0.05$ for the same age. Values represent means \pm SD of 45 replicates (individuals) in the case of dry weight and length, of 9 replicates (three groups per tank) and 3 replicates (tanks) in the case of survival.

Tabla 1. Resumen de peso seco, longitud, tasa de crecimiento relativo (RGR), factor de condición (K) y supervivencia de postlarvas de Solea senegalensis bajo los tratamientos con Artemia (metanauplios de Artemia sp.) e ICES (dieta de coalimentación). Las medias en la columna con letras diferentes son significativamente diferentes a $\alpha=0.05$ para la misma edad. Los valores representan las medias $\pm D E$ de 45 réplicas (individuos) en el caso de peso seco y longitud, de 9 réplicas (tres grupos por tanque) y 3 réplicas (tanques) en el caso de supervivencia.

\begin{tabular}{|c|c|c|c|c|c|c|}
\hline Diet & Rearing days & $\begin{array}{l}\text { Dry weight } \\
\text { (mg) }\end{array}$ & $\begin{array}{l}\text { Total length } \\
\text { (cm) }\end{array}$ & $\begin{array}{c}R G R \\
\left(\% \mathrm{~d}^{-1}\right)\end{array}$ & $\begin{array}{c}K \\
(\%)\end{array}$ & $\begin{array}{c}\text { Survival } \\
\text { (\%) }\end{array}$ \\
\hline \multirow[t]{6}{*}{ Artemia } & 0 & $3.4 \pm 0.71$ & $1.3 \pm 0.08$ & & $0.85 \pm 0.086$ & \\
\hline & 9 & $4.7 \pm 1.62$ & $1.5 \pm 0.13$ & $5.1 \pm 2.27$ & $0.82 \pm 0.053$ & \\
\hline & 23 & $7.7 \pm 3.58 \mathrm{a}$ & $1.7 \pm 0.26$ & $3.4 \pm 1.22$ & $0.82 \pm 0.046$ & \\
\hline & 30 & $7.4 \pm 4.01 \mathrm{a}$ & $1.7 \pm 0.27 \mathrm{a}$ & $1.1 \pm 0.41$ & $0.78 \pm 0.027$ & \\
\hline & 39 & $9.9 \pm 4.86 \mathrm{a}$ & $1.9 \pm 0.23 \mathrm{a}$ & $2.9 \pm 1.47$ & $0.70 \pm 0.094$ & \\
\hline & 46 & $17.9 \pm 14.38 \mathrm{a}$ & $2.2 \pm 0.47 \mathrm{a}$ & $6.1 \pm 7.91$ & $0.78 \pm 0.050 \mathrm{a}$ & $93.5 \pm 1.02 \mathrm{a}$ \\
\hline \multirow[t]{5}{*}{ ICES } & 0 & $3.2 \pm 0.98$ & $1.3 \pm 0.14$ & & $0.80 \pm 0.084$ & \\
\hline & 9 & $4.3 \pm 1.61$ & $1.4 \pm 0.15$ & $3.3 \pm 0.95$ & $0.83 \pm 0.067$ & \\
\hline & 23 & $6.3 \pm 3.72 b$ & $1.6 \pm 0.30$ & $2.7 \pm 1.01$ & $0.79 \pm 0.042$ & \\
\hline & 30 & $5.3 \pm 3.30 b$ & $1.6 \pm 0.28 b$ & $-2.4 \pm 1.28$ & $0.75 \pm 0.051$ & \\
\hline & 39 & $4.2 \pm 1.59 b$ & $1.6 \pm 0.16 b$ & $-2.5 \pm 2.43$ & $0.61 \pm 0.036$ & \\
\hline
\end{tabular}




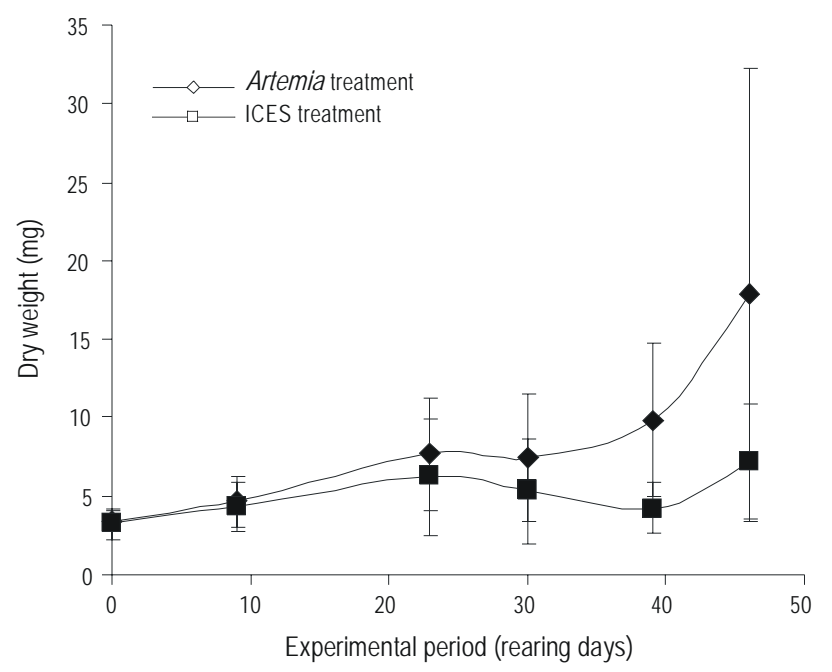

Figure 3. Dry weight growth curve of Solea senegalensis postlarvae under the Artemia (Artemia sp. metanauplii) and ICES (co-feeding diet) treatments. Means $\pm \mathrm{SD}, n=45$.

Figura 3. Curva de crecimiento (peso seco) de postlarvas de Solea senegalensis bajo los tratamientos con Artemia (metanauplios de Artemia sp.) e ICES (dieta de coalimentación). Medias $\pm \mathrm{DE}, n=45$.

treatment than the ICES treatment $(P<0.05)$, being $3.7 \pm 1.02$ and $1.7 \pm 0.19$, respectively.

Throughout the experimental period, $K$ exhibited a similar pattern of variation in both treatments (table 1 ). This value was persistent during the first three samplings. After this period, a decrease in $K$ was observed, being more evident in the ICES treatment; however, the difference between treatments was significant only on day R46 $(P<0.05)$.

\section{Biochemical content}

Protein content exhibited some variability at first sampling in both treatments (table 2). After that point, a small decrease was observed for the Artemia treatment until day R23, followed by an increase until the end of the experiment. For the ICES-fed group, the protein content was more stable during the first 23 days of rearing, but after day R30 it decreased considerably (around 14\%), resulting in significant differences for both treatments on day R46 $(P<0.05)$.

Total lipid content was not significantly affected by the diet (table 2). The pattern of variation was similar between treatments. Lipid content decreased on day R23 in both treatments, though it is more evident in the ICES-fed group, and then increased again until the end of the experiment. Nevertheless, the levels of total lipid reached on day R46 were lower than the initial ones.

\section{Ammonia experiment}

The background level of TAN in the water was almost negligible, and was subtracted to the TAN values obtained from the experimental tanks analyzed. tratamiento con Artemia y se incrementó durante el periodo experimental. El tratamiento ICES presentó un patrón similar, aunque se observó una disminución el día 39 de cultivo.

La TCR mostró una fuerte variación durante el periodo experimental, decreciendo después del día 23 de cultivo para volver a incrementarse al final del experimento. El decrecimiento fue más evidente en el tratamiento ICES, especialmente los días 30 y 39 de cultivo, cuando se obtuvieron valores negativos de TCR (tabla 1). No obstante, las postlarvas alimentadas con la dieta ICES pudieron recuperarse y presentaron una mayor TCR el día 46 de cultivo que las postlarvas alimentadas con Artemia. La TCR global fue significativamente mayor para el tratamiento con Artemia que para el de ICES $(P<0.05)$, siendo $3.7 \pm 1.02$ y $1.7 \pm 0.19$, respectivamente.

A lo largo del periodo experimental, $K$ mostró un patrón de variación similar en ambos tratamientos (tabla 1). Este valor fue persistente durante los primeros tres muestreos. Posteriormente se observó una reducción de $K$, más evidente en el tratamiento ICES; sin embargo, sólo se observó un efecto significativamente diferente $(P<0.05)$ entre tratamientos el día 46 de cultivo.

\section{Contenido bioquímico}

El contenido de proteína mostró cierta variabilidad en el primer muestreo en ambos tratamientos (tabla 2). Posteriormente se registró una pequeña reducción en el tratamiento con Artemia hasta el día 23 de cultivo, seguido por un incremento hasta el final del experimento. En el tratamiento ICES el contenido de proteína fue más estable durante los primeros 23 días de cultivo, pero decreció considerablemente (alrededor de 14\%) después del día 30; por tanto, hubo una diferencia significativa entre tratamientos el día 46 de cultivo $(P<0.05)$.

El contenido de lípidos totales no fue afectado significativamente por la dieta (tabla 2). El patrón de variación fue similar para ambos tratamientos. El contenido de lípidos decreció el día 23 de cultivo, aunque esto fue más evidente en el tratamiento ICES, y luego volvió a aumentar hasta el final del experimento. No obstante, los niveles de lípidos totales al día 46 de cultivo fueron menores que los iniciales.

\section{Experimento de amonio total}

La concentración inicial de TAN en el agua fue prácticamente despreciable, restándose a los valores de TAN obtenidos de los tanques experimentales analizados.

Al suministrar la comida, las concentraciones de TAN fueron $0.37 \pm 0.01$ y $0.36 \pm 0.02 \mathrm{mg} \mathrm{L}^{-1}$ para los tratamientos con Artemia e ICES, respectivamente (fig. 1). Posteriormente, la variación en el nivel de TAN fue diferente en cada tratamiento. En el tratamiento ICES, la concentración de TAN aumentó una hora después de la alimentación matutina y de la vespertina a $0.56 \pm 0.07$ y $0.4 \pm 0.01 \mathrm{mg} \mathrm{TAN} \mathrm{L}^{-1}$, respectivamente, y luego decreció gradualmente. En el tratamiento con Artemia, la concentración de TAN aumentó una hora después 
Table 2. Protein and total lipid content of Solea senegalensis postlarvae under the Artemia (Artemia sp. metanauplii) and ICES (co-feeding diet) treatments, and the diets used. The values are expressed as percentage of postlarval dry weight. The means in a row bearing different letters are significantly different at $\alpha=0.05$ for the same age. Means $\pm \mathrm{SD}, n=3$.

Tabla 2. Contenido de proteína y lípidos totales de postlarvas de Solea senegalensis bajo los tratamientos con Artemia (metanauplios de Artemia sp.) e ICES (dieta de coalimentación), y las dietas usadas. Los valores se expresan en porcentaje de peso seco de postlarvas. Las medias en un renglón con letras diferentes son significativamente diferentes a $\alpha=0.05$ para la misma edad. Medias $\pm D E, n=3$.

\begin{tabular}{lccccc}
\hline & \multicolumn{2}{c}{ Artemia } & & \multicolumn{2}{c}{ ICES } \\
\cline { 2 - 3 } \cline { 5 - 6 } & Protein (\%) & Total lipids (\%) & & Protein (\%) & Total lipids (\%) \\
\hline Diets & $40.4 \pm 3.53 \mathrm{~b}$ & $14.4 \pm 0.66 \mathrm{a}$ & & $54.0 \pm 4.73 \mathrm{a}$ & $9.8 \pm 1.99 \mathrm{~b}$ \\
& & & & \\
Rearing day 0 & $57.2 \pm 10.45$ & $10.1 \pm 1.19$ & & $54.7 \pm 9.88$ & $11.8 \pm 1.31$ \\
Rearing day 9 & $53.3 \pm 6.75$ & $12.1 \pm 1.40$ & & $52.4 \pm 9.07$ & $11.6 \pm 1.25$ \\
Rearing day 23 & $50.5 \pm 1.96 \mathrm{~b}$ & $10.1 \pm 3.48$ & & $55.3 \pm 2.6 \mathrm{a}$ & $7.7 \pm 0.86$ \\
Rearing day 30 & $55.3 \pm 1.29$ & $9.7 \pm 0.40$ & & $54.2 \pm 2.21$ & $8.2 \pm 1.72$ \\
Rearing day 46 & $58.3 \pm 3.39 \mathrm{a}$ & $9.8 \pm 0.82$ & & $46.7 \pm 6.99 \mathrm{~b}$ & $8.3 \pm 0.46$ \\
\hline
\end{tabular}

At food addition, TAN concentrations were $0.37 \pm 0.01$ and $0.36 \pm 0.02 \mathrm{mg} \mathrm{L}^{-1}$ for the Artemia and ICES treatments, respectively (fig. 1). Thereafter, the variation in TAN level was different for each treatment. In the ICES treatment, TAN concentration increased one hour after the morning and afternoon meals to $0.56 \pm 0.07$ and $0.4 \pm 0.01 \mathrm{mg} \mathrm{TAN} \mathrm{L}^{-1}$, respectively, decreasing gradually afterwards. The Artemia treatment presented an increase in TAN concentration one hour after the morning meal to $0.85 \pm 0.004 \mathrm{mg} \mathrm{TAN} \mathrm{L}^{-1}$; afterwards, this value kept decreasing and increasing, reaching the highest value of $1.28 \pm 0.001 \mathrm{mg}$ TAN L $\mathrm{L}^{-1}$ when the afternoon meal was given and decreasing to $0.90 \pm 0.004 \mathrm{mg}^{\mathrm{TAN} \mathrm{L}} \mathrm{L}^{-1}$ one hour after the afternoon meal. Seventeen hours after the last meal, the TAN concentration had decreased to $0.11 \pm 0.016$ and $0.06 \pm 0.021 \mathrm{mg} \mathrm{TAN} \mathrm{L}^{-1}$ in the Artemia and ICES treatments, respectively.

Since fish biomass was different for each treatment, the TAN values were also expressed relative to fish biomass (mg TAN L-1 $\mathrm{kg}^{-1}$ fish). The pattern observed in TAN variation taking into account fish biomass in the tanks was similar to that previously described, although the differences were not so evident between treatments until three hours after the first meal (fig. 2).

\section{Discussion}

Senegalese sole postlarvae from the ICES treatment adapted to the diet at the end of the experiment, but postlarvae from the Artemia treatment exhibited significantly higher values for growth, survival, $R G R, K$, and protein and total lipid contents.

The survival rate of Senegalese sole postlarvae fed Artemia sp. was higher than values previously reported for this species (Dinis, 1992; Marin-Magan et al., 1995; Cañavate and Fernández-Díaz, 1999), while growth rate was identical to that de la alimentación matutina a $0.85 \pm 0.004 \mathrm{mg}$ TAN L ${ }^{-1}$; después, este valor continuó disminuyendo y aumentando, hasta alcanzar un máximo de $1.28 \pm 0.001 \mathrm{mg} \mathrm{TAN} \mathrm{L}^{-1}$ al suministrar el alimento vespertino y disminuyendo, una hora después, a $0.90 \pm 0.004 \mathrm{mg} \mathrm{TAN} \mathrm{L}^{-1}$. Diecisiete horas después del último alimento, la concentración de TAN había disminuido a $0.11 \pm 0.016$ y $0.06 \pm 0.021 \mathrm{mg} \mathrm{TAN} \mathrm{L}^{-1}$ con Artemia e ICES, respectivamente.

En vista de que la biomasa de peces fue diferente en cada tratamiento, también se estimaron los valores de TAN en relación con la biomasa (mg TAN L $\mathrm{L}^{-1} \mathrm{~kg}^{-1}$ pez). El patrón de variación de TAN considerando la biomasa en los tanques fue similar al descrito anteriormente, aunque las diferencias no fueron tan evidentes entre tratamientos hasta tres horas después del primer alimento (fig. 2).

\section{Discusión}

Las postlarvas de $S$. senegalensis del tratamiento ICES se adaptaron a la dieta al final del experimento, pero las postlarvas del tratamiento con Artemia presentaron valores significativamente mayores de crecimiento, supervivencia, $T C R, K$ y contenidos de proteína y lípidos.

La tasa de supervivencia de las postlarvas alimentadas con Artemia sp. fue mayor que los resultados obtenidos anteriormente para esta especie (Dinis, 1992; Marin-Magan et al., 1995; Cañavate y Fernández-Díaz, 1999); sin embargo, la tasa de crecimiento fue idéntica a la registrada por Marin-Magan et al. (1995), pero menor que los valores obtenidos por Cañavate y Fernández-Díaz (1999).

En el tratamiento utilizando una dieta compuesta, la tasa de supervivencia fue mayor que los valores obtenidos por Dinis (1992), Marin-Magan et al. (1995) y Cañavate y FernándezDíaz (1999), pero no fue mayor comparada con los de Engrola et al. (2001). Por otro lado, la tasa de crecimiento fue similar 
reported by Marin-Magan et al. (1995), but lower than the values obtained by Cañavate and Fernández-Díaz (1999).

In the treatment where fish were fed a compound diet, the survival rate obtained was higher than the values reported by Dinis (1992), Marin-Magan et al. (1995) and Cañavate and Fernández-Díaz (1999), except compared with Engrola et al. (2001). On the other hand, the growth rate results were similar to those obtained by Dinis (1992), but much lower than the values reported by other authors (Marin-Magan et al., 1995; Cañavate and Fernández-Díaz, 1999; Engrola et al., 2001).

The low RGR observed could be associated with the high survival rate. Nevertheless, analyzing the results obtained in different studies on Senegalese sole fed a compound diet (Dinis, 1992; Marin-Magan et al., 1995; Cañavate and Fernández-Díaz, 1999; Engrola et al., 2001), there was no significant correlation between $R G R$ and survival rates $(r=0.11 ; P=$ 0.672; $n=16$ ).

The age of sole larvae at the beginning of weaning was similar among studies, but the dry weight at that moment was substantially different in all the studies that reported weight (Marin-Magan et al., 1995; Cañavate and Fernández-Díaz, 1999; Engrola et al., 2001). In this case, we observed a positive correlation between the initial dry weight and the $R G R$ obtained $(y=0.12 x+3.52, r=0.68 ; P<0.05 ; n=12)$. Nevertheless, the relation between initial dry weight and survival rate was not significant $(r=0.31 ; P=0.325 ; n=12)$.

From previous experience with this species it seems that the acquisition of new structures during larval development and the beginning of metamorphosis is more related to fish larval size than to fish age, within the same spawn. FernándezDíaz et al. (2001) observed that Senegalese sole larvae with lower growth rate started metamorphosis a few days later than those exhibiting higher growth rates. Some authors (Verreth, 1994; Roselund et al., 1997) previously reported the high accuracy of larval weight rather than age as an indicator of the physiological and development status of larvae, suggesting that for the same age, bigger larvae will be more developed than smaller larvae. The fact that Senegalese sole postlarvae exhibited a lower weight, independently of age, when compared with other studies on this species, suggests that these postlarvae could be less developed and consequently less prepared to adapt to a compound diet.

Fish density in the tanks may have contributed to the low growth observed during the experiment. Due to the high number of larvae needed for the analytical purposes of this study, the initial density was 2000 larvae $\mathrm{m}^{-2}$, which was reduced to 1200 larvae $\mathrm{m}^{-2}$ within three weeks. This initial value is $33 \%$ lower than that reported by Cañavate and Fernández-Díaz (1999) that used an initial value of 3000 larvae $\mathrm{m}^{-2}$, and it is $45 \%$ lower on a weight basis ( $13.2 \mathrm{~g}$ dry weight $\mathrm{m}^{-2}$ ) than the value used by those authors (Cañavate and Fernández-Díaz, 1999; $24 \mathrm{~g}$ dry weight $\mathrm{m}^{-2}$ ). Both values represent lower density values when compared with the values used for Dover sole, Solea solea (Day et al., 1997; $58 \mathrm{~g}$ of fish dry weight $\mathrm{m}^{-2}$, with 50-60 days). a la obtenida por Dinis (1992), pero mucho menor que la obtenida por otros autores (Marin-Magan et al., 1995; Cañavate y Fernández-Díaz, 1999; Engrola et al., 2001).

La baja TCR observada puede estar asociada con la alta tasa de supervivencia; sin embargo, al analizar los resultados obtenidos en otros estudios sobre el lenguado senegalés alimentado con una dieta compuesta (Dinis, 1992; Marin-Magan et al., 1995; Cañavate y Fernández-Díaz, 1999; Engrola et al., 2001), no se encontró una correlación significativa entre la tasa de supervivencia y TCR $(r=0.11 ; P=0.672 ; n=16)$.

La edad de las larvas de lenguado al inicio del destete fue similar entre estudios, pero el peso seco en ese momento fue sustancialmente diferente en todos los estudios que consideraron peso (Marin-Magan et al., 1995; Cañavate y Fernández-Díaz, 1999; Engrola et al., 2001). En este caso, se observó una correlación positiva entre el peso seco inicial y la TCR $(y=0.12 x+3.52, r=0.68 ; P<0.05 ; n=12)$, aunque la relación entre el peso seco inicial y la tasa de supervivencia no fue significativa ( $r=0.31 ; P=0.325 ; n=12$ ).

Experiencia previa con esta especie ha indicado que la adquisición de estructuras nuevas durante el desarrollo larval y el inicio de la metamorfosis parece estar relacionada más con la talla larval que con la edad, dentro del mismo desove. Fernández-Díaz et al. (2001) observaron que las larvas de $S$. senegalensis con menor tasa de crecimiento comienzan la metamorfosis unos cuantos días después que las larvas con mayor tasa de crecimiento. Algunos autores (Verreth, 1994; Roselund et al., 1997) han comentado sobre la gran precisión del peso larval como indicador del estado fisiológico y de desarrollo de las larvas en comparación con la edad, lo que indica que para la misma edad, las larvas más grandes presentarán mayor desarrollo que las larvas más pequeñas. El hecho de que, independientemente de la edad, el peso de las postlarvas de $S$. senegalensis fue menor que lo reportado en otros estudios sobre esta especie, sugiere que las postlarvas pueden estar menos desarrolladas y consecuentemente menos preparadas para adaptarse a la dieta compuesta.

La densidad de peces en los tanques pudo haber contribuido al bajo crecimiento durante el experimento. Debido al elevado número de larvas requerido para los propósitos analíticos de este estudio, la densidad inicial fue de 2000 larvas $\mathrm{m}^{-2}$, disminuyendo a 1200 larvas $\mathrm{m}^{-2}$ en tres semanas. Este valor inicial es 33\% menor que los valores obtenidos por Cañavate y Fernández-Díaz (1999), quienes usaron un valor inicial de 3000 larvas $\mathrm{m}^{-2}$, y es $45 \%$ menor (13.2 g peso seco $\mathrm{m}^{-2}$ ) con respecto al peso reportado por esos mismos autores (Cañavate y Fernández-Díaz, 1999; 24 g peso seco $\mathrm{m}^{-2}$ ). Ambos valores representan una densidad menor en comparación con los valores utilizados para el lenguado Solea solea (Day et al., 1997; 58 g peso seco $\mathrm{m}^{-2}$, con 50-60 días).

En el tratamiento ICES se obtuvieron valores menores de los parámetros de crecimiento (crecimiento, TCR, K) a partir del día 23 de cultivo, cuando la cantidad de la dieta ICES aumentó por arriba de $50 \%$ en la ración diaria. Este hecho 
The lower values obtained for growth parameters (growth, $R G R, K$ ) for the ICES treatment postlarvae were observed after day R23, coinciding with the increase above $50 \%$ of the ICES diet in the daily ration. This fact suggests that postlarvae had difficulties in adapting to the compound diet, which led to the increase in mortality rate from this moment onwards; however, ICES-fed larvae were able to start feeding on the compound diet as verified by the increase in $R G R$ by the end of the experiment. The slow introduction of the diet at this stage of postlarval development, resulting in a long period of cofeeding, did not appear to be a suitable weaning strategy, since postlarvae get used to ingest live feed in their daily ration. Roselund et al. (1997) observed that fish larvae became preconditioned to live feed as a consequence of co-feeding. Though the ICES treatment exhibited lower $R G R$ values, postlarvae from the Artemia treatment also exhibited a delay in growth, suggesting that there were other factors influencing postlarval condition apart from the nutritional ones, or that both diets were suboptimal.

No significant effect of the ICES diet was observed on the postlarval body composition. The long period of co-feeding when ICES postlarvae were mainly eating Artemia sp. can justify this observation. In fact, the decrease in $R G R$ after the concomitant increase of the ICES diet in the daily ration also reinforces this observation. Even if the amount of live food was insufficient to fulfill postlarval energetic requirements, leading to a decrease in growth, a proportional mobilization of body components would have maintained the protein and lipid contents at the same value. Total lipid content of ICES postlarvae at day R23 decreased although protein content and dry weight increased, suggesting that total lipids were mobilized for energetic purposes. At the following sampling points, the decrease in dry weight was more evident and protein content also decreased, reflecting a situation of food scarcity. Biologi$\mathrm{cal}$ and environmental factors influence the pattern of nutrient depletion in body composition (Hung et al., 1997).

Ammonia may become a limiting factor for growth and even survival of fish (Person-Le-Ruyet et al., 1997). The TAN concentration in water was kept lower than $1 \mathrm{mg} \mathrm{L}^{-1}$ for both treatments, although postlarvae from the Artemia treatment were exposed for two hours above this value (1.28 mg TAN L ${ }^{-1}$ ). Parra and Yúfera (1999) observed that total mortality was attained when Senegalese sole larvae were exposed to $80 \mathrm{mg} \mathrm{L}^{-1}$ of ammonia (TAN). Based on water temperature, oxygen and $\mathrm{pH}$, these authors calculated a 24-h $\mathrm{LC}_{50}\left(\mathrm{NH}_{3}\right)$ of $1.32 \mathrm{mg} \mathrm{L}^{-1}$ for this species (1.6\% of TAN). According to Person-Le Ruyet (1997), unionized ammonia $\left(\mathrm{NH}_{3}\right)$ corresponds to $2-4 \%$ of TAN in saltwater. Using these reference values, the concentration of $\mathrm{NH}_{3}$ obtained for the higher value observed in the present study corresponds to 0.03-0.05 mg NH $\mathrm{L}_{3} \mathrm{~L}^{-1}$, well below the value of $0.13 \mathrm{mg} \mathrm{L}^{-1}$ recommended by Parra and Yúfera (1999) to prevent deaths.

Food degradation and organic detritus may contribute to increase the level of ammonia in water; however, TAN present in the rearing water mainly originates from excretion (Jobling, sugiere que las postlarvas tuvieron dificultad para adaptarse a la dieta compuesta, resultando en un aumento en la tasa de mortandad a partir de ese momento; sin embargo, las larvas de este tratamiento pudieron empezar a alimentarse con la dieta compuesta, lo cual es confirmado por el aumento en TCR al final del experimento. La introducción lenta de la dieta en esta etapa de desarrollo postlarval, que resultó en un periodo largo de coalimentación, no parece ser una estrategia adecuada para el destete ya que las postlarvas se acostumbran a recibir alimento vivo en su ración diaria. Roselund et al. (1997) observaron que las larvas de peces se acostumbran al alimento vivo como consecuencia de la coalimentación. A pesar de que el tratamiento ICES arrojó valores de TCR más bajos, las postlarvas del tratamiento con Artemia también mostraron un retraso en crecimiento, lo que sugiere que existieron otros factores además de los nutricionales que influenciaron la condición postlarval, o que ambas dietas fueron subóptimas.

No se observó ningún efecto significativo de la dieta ICES en la composición corporal de las postlarvas. El largo periodo de coalimentación cuando las postlarvas del tratamiento ICES se alimentaban principalmente de Artemia sp. puede justificar esta observación. De hecho, la disminución en TCR después del incremento concomitante de la dieta ICES en la ración diaria refuerza esta observación. Aun cuando la cantidad de alimento vivo es insuficiente para satisfacer las necesidades energéticas de las postlarvas, resultando en una disminución del crecimiento, una mobilización proporcional de componentes corporales hubiera mantenido los contenidos de proteína y lípidos al mismo nivel. El contenido de lípidos totales decreció en las postlarvas del tratamiento ICES el día 23 de cultivo, aunque su contenido de proteína y peso seco aumentaron; esto sugiere que los lípidos totales fueron mobilizados para propósitos energéticos. En los puntos de muestreo siguientes fue más evidente la disminución del peso seco, disminuyendo también el contenido de proteína, lo que refleja una situación de escasez de alimento. Factores biológicos y ambientales afectan el patrón de agotamiento de nutrientes en la composición corporal (Hung et al., 1997).

El amonio se puede convertir en un factor limitante para el crecimiento y aun para la supervivencia de peces (Person-LeRuyet et al., 1997). La concentración de TAN en el agua se mantuvo por debajo de $1 \mathrm{mg} \mathrm{L}^{-1}$ en ambos tratamientos, aunque las postlarvas del tratamiento con Artemia fueron expuestas durante dos horas a un valor mayor (1.28 mg TAN $\mathrm{L}^{-1}$ ). Parra y Yúfera (1999) observaron que las larvas de $S$. senegalensis expuestas a $80 \mathrm{mg} \mathrm{L}^{-1}$ de amonio (TAN) sufrieron una mortandad total. Con base en la temperatura, el oxígeno y el $\mathrm{pH}$ del agua, estos autores calcularon un $\mathrm{LC}_{50}\left(\mathrm{NH}_{3}\right)$ a las 24 h de $1.32 \mathrm{mg} \mathrm{L}^{-1}$ para esta especie (1.6\% de TAN). Según Person-Le-Ruyet (1997), el amonio no ionizado $\left(\mathrm{NH}_{3}\right)$ corresponde a $2-4 \%$ del TAN en agua de mar. Utilizando estos valores de referencia, la concentración de $\mathrm{NH}_{3}$ obtenida para el mayor valor registrado en el presente estudio corresponde a 0.03-0.05 mg NH $\mathrm{L}_{3} \mathrm{~L}^{-1}$, considerablemente por debajo del valor 
1994; Person-Le-Ruyet et al., 1997). Some authors report that the quantity of TAN can be related to the amount of food eaten (Jobling, 1994; Lawson, 1995). The TAN values and the sharp decrease in growth exhibited by the ICES treatment postlarvae when $60 \%$ of the ICES diet was added to the daily ration, reinforces the idea that postlarvae were not eating the ICES diet properly.

The strong variation in TAN concentration observed in the Artemia treatment may be justified by the feeding behavior of Soleidae species of eating small amounts for a long period of time (De Groot, 1971), and also by the high postlarval size dispersion observed, which can lead to several moments of ammonia excretion. According to Parra and Yúfera (1999), fluctuating levels of TAN may have a more toxic effect than a continuous exposure.

The peak of TAN observed for Senegalese sole occurred one hour after the first meal; this is faster than that reported in other studies on flatfish species, where the peak occurred three hours after the first meal (Kikuchi et al., 1991, 1995; Verbeeten et al., 1999). Kikuchi et al. (1995) observed that younger fishes had a higher level of daily ammonia excretion. The higher metabolic rates observed in early life stages (Conceição, 1997) as well as the temperature (Brett and Groves, 1979) at which this experiment was conducted could justify the faster response of ammonia excretion.

Postlarvae from the ICES treatment were weaned by the end of the experimental period; however, the Artemia treatment postlarvae exhibited a better performance. The adoption of a long period of co-feeding seemed to have delayed postlarval adaptation to an inert diet, leading to a decrease in their condition and making weaning more difficult. A long period of co-feeding seems to be advantageous for larval stages (PersonLe-Ruyet et al., 1993; Cañavate and Fernández-Díaz, 1999; Baskerville-Bridges and Kling, 2000), but appears not to be the most suitable for Senegalese sole postlarvae.

\section{Acknowledgements}

Laura Ribeiro acknowledges receiving a Ph.D. grant (Praxis XXI: BD/5057/95). This study was supported by the project Praxis XXI 3/3.2/Aq/2023/95.

\section{References}

Baskerville-Bridges, B. and Kling, L.J. (2000). Early weaning of Atlantic cod (Gadus morhua) larvae onto a microparticulate diet. Aquaculture, 189: 109-117.

Blair, T., Castell, J., Neil, S., D’Abramo, L., Cahu, C., Harmon, P. and Ogunmoye, K. (2003). Evaluation of microdiets versus live feeds on growth, survival and fatty acid composition of larval haddock (Melanogrammus aeglefinus). Aquaculture, 225(1-4): 451-461.

Bligh, E.G. and Dyer, W.J. (1959). A rapid method of total lipid extraction and purification. Can. J. Biochem. Physiol., 37(8): 911-917.

Brett, J.R. and Groves, T.D.D. (1979). Physiological energetics. In: W.S. Hoar, D.J. Randalland and J.R. Brett (eds.), Fish Physiology. Academic Press, London, Vol. VIII, pp. 279-352. de $0.13 \mathrm{mg} \mathrm{L}^{-1}$ recomendado por Parra y Yúfera (1999) para prevenir la muerte de los organismos.

La degradación del alimento y el detrito orgánico pueden contribuir a incrementar el nivel de amonio en el agua; sin embargo, el TAN en el agua de cultivo se origina principalmente por excreción (Jobling, 1994; Person-Le-Ruyet et al., 1997). Algunos autores mencionan que la cantidad de TAN puede relacionarse con la cantidad de alimento consumido (Jobling, 1994; Lawson, 1995). Los valores de TAN y la fuerte disminución del crecimiento en las postlarvas del tratamiento ICES, en el momento de muestreo en que la dieta ICES comprendía $60 \%$ de la ración diaria, refuerza la idea de que las postlarvas no estaban consumiendo la dieta ICES en su totalidad.

La gran variación en la concentración de TAN en el tratamiento con Artemia puede justificarse por el comportamiento alimenticio de especies de la familia Soleidae de comer pequeñas cantidades durante un periodo largo de tiempo (De Groot, 1971), así como por la gran dispersión de talla de las postlarvas, lo que puede resultar en varios momentos de excreción de amonio. De acuerdo con Parra y Yúfera (1999), niveles fluctuantes de TAN pueden tener un efecto más tóxico que una exposición continua.

El pico en la concentración de TAN observado para $S$. senegalensis se presentó una hora después del primer alimento; esto es más rápido que lo mencionado en otros estudios de peces planos, en los que éste se ha observado tres horas después del primer alimento (Kikuchi et al., 1991, 1995; Verbeeten et al., 1999). Kikuchi et al. (1995) encontraron que peces más jóvenes tienen un nivel más elevado de excreción de amonio. Las mayores tasas metabólicas en estadios tempranos (Conceição, 1997), así como la temperatura (Brett y Groves, 1979) a la cual se realizó este experimento pueden justificar la respuesta más rápida de excreción de amonio.

Las postlarvas del tratamiento ICES fueron destetadas al final del periodo experimental; sin embargo, las postlarvas del tratamiento con Artemia presentaron un mejor desempeño. La adopción de un periodo largo de coalimentación parece haber demorado la adaptación de las postlarvas a una dieta inerte, resultando en una reducción en su condición y dificultando el destete. Un periodo largo de coalimentación parece ser ventajoso para etapas larvales (Person-Le-Ruyet et al., 1993; Cañavate y Fernández-Díaz, 1999 Baskerville-Bridges y Kling, 2000), pero no resulta ser lo más adecuado para las postlarvas del lenguado senegalés.

\section{Agradecimientos}

Laura Ribeiro fue beneficiaria de una beca doctoral (Praxis XXI: BD/5057/95). Este estudio recibió apoyo del proyecto Praxis XXI 3/3.2/Aq/2023/95.

Traducido al español por Christine Harris. 
Cahu, C. and Zambonino-Infante, J.L. (2001). Substitution of live food by formulated diets in marine fish larvae. Aquaculture, 200: $161-180$.

Cañavate, J.P. and Fernández-Díaz, C. (1999). Influence of cofeeding larvae with live and inert diets on weaning the sole Solea senegalensis onto commercial dry feeds. Aquaculture, 174: 255-263.

Conceição, L.E.C. (1997). Growth in Early Life Stages of Fishes: An Explanatory Model. Wageningen Agricultural Univ., Wageningen, pp. 209.

Coutteau, P., Stappen, G.V. and Sorgeloos, P. (1995). A standard experimental diet for the study of fatty acid requirements of weaning and first ongrowing stages of European sea bass (Dicentrarchus labrax L.): Selection of the basal diet. ICES Mar. Sci. Symp., 201: 130-137.

Day, O.J., Howell, B.R. and Jones, D.A. (1997). The effect of dietary hydrolysed fish protein concentrate on the survival and growth of juvenile Dover sole, Solea solea (L.), during and after weaning. Aquacult. Res., 28: 911-921.

De Groot, S.J. (1971). On the interrelationships between morphology of the alimentary tract, food and feeding behaviour in flatfishes (Pisces: Pleuronectiformes). Neth. J. Sea Res., 5(2): 121-196.

Dinis, M.T. (1992). Aspects of the potential of Solea senegalensis Kaup for aquaculture: Larval rearing and weaning to an artificial diet. J. Aquacult. Fish. Manage., 23: 512-520.

Dinis, M.T., Ribeiro, L., Soares, F. and Sarasquete, C. (1999). A review on the cultivation potential of Solea senegalensis in Spain and Portugal. Aquaculture, 176: 27-38.

Engrola, S., Conceição, L.E.C. and Dinis, M.T. (2001) Effect of preweaning feeding regime on weaning success of Solea senegalensis. In: C.I. Hendry, G.V. Stappen, M. Willeand and P. Sorgeloos (eds.), LARVI'01: Fish and Shellfish Larviculture Symposium. European Aquaculture Society, Ghent, Vol. 30, pp. 178-181.

Fernández-Díaz, C., Yúfera, M., Cañavate, J.P., Moyano, F.J., Alarcón, F.J. and Díaz, M. (2001). Growth and physiological changes during metamorphosis of Senegal sole reared in laboratory. J. Fish Biol., 58: 1086-1097.

Hart, P.R. and Purser, G.J. (1996). Weaning of hatchery-reared greenback flounder (Rhombosolea tapirina Gunther) from live to artificial diets: Effects of age and duration of the changeover period. Aquaculture, 145: 171-181.

Hung, S.S.O., Liu, W., Li, H., Storebakken, T. and Cui, Y. (1997). Effect of starvation on some morphological and biochemical parameters in white sturgeon, Acipenser transmontanus. Aquaculture, 151: 357-363.

Jobling, M. (1994). Fish Bioenergetics. Chapman \& Hall, London, pp. 309.

Kanazawa, A., Koshio, S. and Teshima, S. (1989). Growth and survival of red sea bream Pagrus major and Japanese flounder Paralichthys olivaceus fed microbound diets. J. World Aquacult. Soc., 20: 31-37.

Kikuchi, K., Takeda, S., Honda, H. and Kiyono, M. (1991). Effect of feeding on nitrogen excretion of Japanese flounder Paralichthys olivaceus. Nippon Suisan Gakkaishi, 57(11): 2059-2064.
Kikuchi, K., Sato, T., Iwata, N., Sakaguchi, I. and Deguchi, Y. (1995). Effects of temperature on nitrogenous excretion of Japanese flounder. Fish. Sci., 61(4): 604-607.

Koroleff, F. (1983). Determination of urea. In: K. Grasshoff, M. Ehrhardtand and K. Kremling (eds.), Methods of Seawater Analysis. Verlag Chemie, Weinheim, Germany, pp. 158-162.

Lawson, T.B. (1995). Fundamentals of Aquaculture Engineering. Chapman \& Hall, New York, pp. 355.

Lowry, O.H., Rosebrough, N.J., Farr, L.A. and Randall, R.J. (1951). Protein determination with the folin phenol reagent. J. Biol. Chem., 193: 265-275.

Marin-Magan, V., Anguis, V. y Canavete, J.P. (1995) Uso de alimento inerte en larvas y alevines del lenguado Solea senegalensis. En: F. Castelló i Orvay and A. Calderer i Reig (eds.), V Congreso Nacional de Acuicultura, 10-13 mayo. Universitat de Barcelona, Sant Carles de la Ràpita, pp. 432-436.

Parra, G. and Yúfera, M. (1999). Tolerance response to ammonia and nitrite exposure in larvae of two marine fish species (gilthead seabream Sparus aurata L. and Senegal sole Solea senegalensis Kaup). Aquacult. Res., 30: 857-863.

Person-Le-Ruyet, J., Alexandre, J.C., Thébaud, L. and Mugnier, C. (1993). Marine fish larvae feeding: Formulated diets or live prey? J. World Aquacult. Soc., 24(2): 211-224.

Person-Le-Ruyet, J., Delbard, C., Chartois, H. and Delliou, H.L. (1997). Toxicity of ammonia to turbot juveniles. 1. Effects on survival, growth and food utilisation. Aquat. Living Resour., 10: 307-314.

Ribeiro, L., Conceição, L.E.C. and Dinis, M.T. (1999a). Preliminary results on the effect of the dietary protein/lipid ratio on the growth of Solea senegalensis post larvae In: Proceedings of the World Aquaculture'99. World Aquaculture Society, Sydney, Australia, 170 pp.

Ribeiro, L., Sarasquete, C. and Dinis, M.T. (1999b). Histological and histochemical development of the digestive system of Solea senegalensis (Kaup, 1858) larvae. Aquaculture, 171: 293-308.

Ricker, W.E. (1958). Handbook of computations for biological statistics of fish populations. Can. J. Fish. Aquat. Sci., 119: 1-300.

Roselund, G., Stoss, J. and Talbot, C. (1997). Co-feeding marine fish larvae with inert and live diets. Aquaculture, 155: 183-191.

Rutter, W.J. (1967). Protein determinations in embryos. In: F.H. Wittand and N.K. Wessels (eds.), Methods in Developmental Biology. Academic Press, New York, pp. 671-684.

Sokal, R.R. and Rohlf, F.J. (1995). Biometry. W.H. Freeman and Co., New York, 887 pp.

Verbeeten, B.E., Carter, C.G. and Purser, G.J. (1999). The combined effect of feeding time and ration on growth performance and nitrogen metabolism of greenback flounder. J. Fish Biol., 55: 1328-1343.

Verreth, J. (1994). Nutrition and Related Ontogenetic Aspects in Larvae of the African Catfish, Clarias gariepinus. University of Wageningen, Wageningen, 205 pp. 